\title{
Lavender- and lavandin-distilled straws: an untapped feedstock with great potential for the production of high-added value compounds and fungal enzymes
}

\author{
Laurence Lesage-Meessen ${ }^{1}$, Marine Bou ${ }^{1}$, Christian Ginies², Didier Chevret ${ }^{3}$, David Navarro', Elodie Drula ${ }^{1,4}$, \\ Estelle Bonnin ${ }^{5}$, José C. del Río ${ }^{6}$, Elise Odinot ${ }^{1}$, Alexandra Bisotto ${ }^{1}$, Jean-Guy Berrin ${ }^{1}$, Jean-Claude Sigoillot ${ }^{1}$, \\ Craig B. Faulds ${ }^{1}$ and Anne Lomascolo ${ }^{1 *}$ (D)
}

\begin{abstract}
Background: Lavender (Lavandula angustifolia) and lavandin (a sterile hybrid of L. angustifolia $\times$ L. latifolia) essential oils are among those most commonly used in the world for various industrial purposes, including perfumes, pharmaceuticals and cosmetics. The solid residues from aromatic plant distillation such as lavender- and lavandin-distilled straws are generally considered as wastes, and consequently either left in the fields or burnt. However, lavender- and lavandin-distilled straws are a potentially renewable plant biomass as they are cheap, non-food materials that can be used as raw feedstocks for green chemistry industry. The objective of this work was to assess different pathways of valorization of these straws as bio-based platform chemicals and fungal enzymes of interest in biorefinery.

Results: Sugar and lignin composition analyses and saccharification potential of the straw fractions revealed that these industrial by-products could be suitable for second-generation bioethanol prospective. The solvent extraction processes, developed specifically for these straws, released terpene derivatives (e.g. T-cadinol, $\beta$-caryophyllene), lactones (e.g. coumarin, herniarin) and phenolic compounds of industrial interest, including rosmarinic acid which contributed to the high antioxidant activity of the straw extracts. Lavender and lavandin straws were also suitable inducers for the secretion of a wide panel of lignocellulose-acting enzymes (cellulases, hemicellulases and oxidoreductases) from the white-rot model fungus Pycnoporus cinnabarinus. Interestingly, high amounts of laccase and several lytic polysaccharide monooxygenases were identified in the lavender and lavandin straw secretomes using proteomics.
\end{abstract}

Conclusions: The present study demonstrated that the distilled straws of lavender and lavandin are lignocellulosicrich materials that can be used as raw feedstocks for producing high-added value compounds (antioxidants, aroma) and fungal oxidative enzymes, which represent opportunities to improve the decomposition of recalcitrant lignocellulose into biofuel. Hence, the structure and the physico-chemical properties of these straws clearly open new perspectives for use in biotechnological processes involving especially filamentous fungi. These approaches represent sustainable strategies to foster the development of a local circular bioeconomy.

Keywords: Lavender and lavandin straws, Sugar and lignin, Terpenes and phenolics, Antioxidant, Pycnoporus cinnabarinus, Laccase, Lytic polysaccharide monooxygenase, Biorefinery

\footnotetext{
*Correspondence: anne.lomascolo@univ-amu.fr

1 UMR1 163 BBF Biodiversité et Biotechnologie Fongiques, INRA, Aix

Marseille Univ, 13288 Marseille Cedex 09, France

Full list of author information is available at the end of the article
} 


\section{Background}

Lavandula species (Lamiaceae family) are mainly grown for their essential oils which are used in perfumes, cosmetics, food processing and aromatherapy products. Three species are cultivated: fine lavender (Lavandula angustifolia), the most common one, spike lavender (Lavandula latifolia) and lavandin (Lavandula $x$ intermedia), a sterile hybrid of $L$. angustifolia $\times$ L. latifolia. The aromatic qualities of lavender and lavandin are mainly due to the volatile compounds found in their essential oil, identified as terpenes or terpenoids [1]. Global production of lavender and lavandin essential oils is estimated at 200 and 1000 tons per year, respectively. Production is located in Europe, Ukraine, Asia and Northern Africa, but dominated by the South of France, which holds a 90\% share of the global market for lavandin essential oil [2].

The essential oil is usually obtained from raw plant materials (flowers, buds, stems and leaves) by steam distillation, but yields are low with only $2-10 \%$ dry matter [1-3]. Consequently, large amounts of solid residues, estimated at around 20,000 tons (dry matter) of lavandinand lavender-distilled straws (LLDS), are generated every year in France [4]. These LLDS residues can be an environmental concern if they are not properly managed, but they are also a significant source of bioactive compounds that can increase the overall profitability of the aromatic plant.

Lavender- and lavandin-distilled straws are generally considered as waste materials and have traditionally been burnt to generate energy or used for composting. However, recycling LLDS by composting carries disadvantages due to the anti-germinative properties of certain components [5]. New alternatives to these traditional uses have emerged that make use of the physicochemical properties and composition of LLDS. Distilled lavender straw was successfully recycled as bio-based aggregates for building materials due to its hygrothermal properties [6]. In addition, many Lamiaceae plants are known to contain a wide range of phenolic compounds with antioxidant activity [7]. As phenolic compounds like hydroxycinnamic acids and flavonoids are not volatile and not degraded by thermal treatment [8], they remain in the waste material after distillation. For instance, antioxidant phenolic compounds, including rosmarinic acid, apigenin and luteolin, were found in spike lavender residues and lavandin wastes $[5,9]$.

A basic chemical composition analysis (nitrogen, carbon, hydrogen, oxygen and sulfur), by the French InterRegional Center for Experimentation in Medicinal and Aromatic Plants [4] revealed that the LLDS were carbon-rich residues (around 50\% dry matter), originating especially from lignocellulose $[2,10]$, the most abundant biopolymer on Earth composed of carbohydrate polymers (cellulose, hemicellulose) and recalcitrant aromatic polymer (lignin) [11]. From a biotechnological point of view, LLDS are a largely untapped biomass resource for sustainable chemistry.

Filamentous fungi are microorganisms that can thrive on a wide variety of lignocellulosic by-products for biotransformation or delignification, including cereal brans, sugar beet pulp, rapeseed and sunflower meal, wheat straw [12-14]. This ability of fungi to degrade lignocellulosic materials is due to their highly efficient and extracellular enzymatic systems: (i) a huge hydrolytic arsenal, which is used, for instance, for the saccharification of lignocellulosic residues generating (after fermentation) second-generation bioethanol $[15,16]$, and (ii) a unique oxidative and lignolytic system, which degrades and modifies aromatic compounds including lignin [17]. In a green chemistry framework, the use of filamentous fungi may be attractive for developing new LLDS valorization routes, given their lignocellulose-degrading enzyme machinery.

The general objective of this work was to assess the potential of LLDS as a feedstock for high-added value bio-based compounds and fungal enzyme production biotechnological processes. LLDS, fractionated into stem straws and flower straws were analyzed in terms of composition and their saccharification potential and antioxidant activity were assessed. The utilization of each fraction of lavender and lavandin straws as substrate for enzyme production and growth of the model whiterot fungus Pycnoporus cinnabarinus was investigated using proteomics. This study opens new prospects for the use of lavender and lavandin by-products in white biotechnology.

\section{Results}

\section{Lignocellulose composition of lavender and lavandin} straws and saccharification potential

The distribution of lignin and polysaccharides in the LLDS fractions is shown in Table 1. The DM content was in the range 92-93\%. Lignin and cellulose amounts were comparable between lavandin and lavender straws, while the composition of stem straws (DS and LS) and flowers straws (DF and LF) differed. The acid-insoluble lignin content was slightly lower in DS and LS $(\sim 25 \%$ DM) than in DF and LF ( 29\% DM). Cellulose content was two-fold higher in DS and LS ( 16-17\% DM) than in DF and LF ( 8\% DM), whereas hemicellulose and pectin contents were similar for stem and flower straws. Cell wall polysaccharide's composition was broadly similar between lavandin and lavender straws. All the fractions yielded rhamnose, mannose, galactose, arabinose, glucose, xylose and galacturonic acids, although the relative amounts of each monomer varied from fraction to 
Table 1 Composition of lavandin- and lavender-distilled straws, expressed as percentage of dry matter

\begin{tabular}{|c|c|c|c|c|}
\hline & Lavandin & & Lavender & \\
\hline & DS & DF & LS & LF \\
\hline Moisture & $6.85 \pm 0.05$ & $6.65 \pm 0.28$ & $7.15 \pm 0.49$ & $7.60 \pm 0.49$ \\
\hline Acid-insoluble lignin & $25.64 \pm 0.33$ & $29.42 \pm 0.57$ & $24.99 \pm 0.34$ & $29.22 \pm 0.48$ \\
\hline Hemicelluloses and pectins & $29.81 \pm 0.59$ & $30.44 \pm 0.06$ & $27.82 \pm 0.19$ & $26.84 \pm 0.07$ \\
\hline Rhamnose $\mathrm{e}^{\mathrm{a}}$ & $0.36 \pm 0.01$ & $0.47 \pm 0.06$ & $0.42 \pm 0.01$ & $0.52 \pm 0.01$ \\
\hline Fucose $^{a}$ & 0 & 0 & 0 & 0 \\
\hline Arabinose $^{a}$ & $1.8 \pm 0.03$ & $3.50 \pm 0.03$ & $1.56 \pm 0.14$ & $2.58 \pm 0.01$ \\
\hline Xylose $^{\mathrm{a}}$ & $14.20 \pm 0.45$ & $5.59 \pm 0.22$ & $13.14 \pm 0.20$ & $6.28 \pm 0.13$ \\
\hline Mannose ${ }^{a}$ & $1.06 \pm 0.02$ & $1.00 \pm 0.01$ & $1.15 \pm 0.02$ & $1.05 \pm 0.11$ \\
\hline Galactose $^{a}$ & $1.32 \pm 0.06$ & $2.94 \pm 0.06$ & $1.35 \pm 0.03$ & $2.16 \pm 0.22$ \\
\hline Glucose $^{\mathrm{a}}$ & $4.51 \pm 0.11$ & $6.39 \pm 0.02$ & $3.16 \pm 0.01$ & $4.47 \pm 0.12$ \\
\hline Galacturonic acids ${ }^{\mathrm{a}}$ & $6.58 \pm 0.00$ & $10.56 \pm 0.00$ & $7.05 \pm 0.00$ & $9.80 \pm 0.00$ \\
\hline Cellulose & $16.06 \pm 0.50$ & $7.95 \pm 0.03$ & $17.49 \pm 0.06$ & $8.23 \pm 0.46$ \\
\hline
\end{tabular}

The experiments were performed in duplicate $(n=2)$

$D S$ lavandin stem straw, DF lavandin flower straw, $L S$ lavender stem straw, LF lavender flower straw

a Monomer analysis after hydrolysis (see "Methods")

fraction. The rhamnose, arabinose, galactose and galacturonic acid contents, mainly pectin constituents, were higher in flower straws than in stem straws. Conversely, xylose content was higher in stem straws than in flower straws.

The lignin composition of the LLDS fractions (DS, DF, LS and LF) was characterized by Py-GC/MS. Pyrolysis produces a thermal breakdown of the lignin polymer into monomeric fragments that can be readily analyzed by GC-MS and is a useful tool to determine lignin composition in terms of the $p$-hydroxyphenyl $(\mathrm{H})$, guaiacyl $(\mathrm{G})$ and syringyl (S) lignin units and the $S / G$ ratios of plant samples [18]. In all cases, the pyrograms of the LLDS fractions mostly showed compounds derived from carbohydrates, terpenoids and proteins, whereas the ligninderived compounds were present in lower amounts. Among the lignin-derived compounds, the pyrograms showed compounds derived from G-lignin units such as guaiacol, 4-methylguaiacol, 4-ethylguaiacol, 4-vinylguaiacol and trans-4-propenylguaiacol, and compounds derived from S-lignin units such as syringol, 4-methylsyringol, 4-ethylsyringol, 4-vinylsyringol and trans-4-propenylsyringol (Table 2). The lignin composition of the LLDS fractions (in terms of their S/G ratios) was estimated from the peak areas of the respective compounds in the pyrograms and indicated that the stem straws (DS and LS) presented similar amounts of G- and S-lignin units (S/G ratios of 0.9), whereas the flower straws (DF and LF) were highly enriched in G-lignin units (S/G ratios of $0.2-0.3)$.

Saccharification of DS, DF, LS and LF fractions was performed using a Trichoderma reesei enzymatic
Table 2 Selected G- and S-lignin-derived compounds released upon Py-GC/MS of the different samples, and S/G ratios

\begin{tabular}{|c|c|c|c|c|}
\hline & \multicolumn{2}{|c|}{ Lavandin } & \multicolumn{2}{|c|}{ Lavender } \\
\hline & DS & DF & LS & LF \\
\hline \multicolumn{5}{|l|}{ Py-GC/MS analysis ${ }^{\mathrm{a}}$} \\
\hline \multicolumn{5}{|c|}{ Guaiacyl-derived compounds } \\
\hline Guaiacol & 31.4 & 28.0 & 39.3 & 13.1 \\
\hline 4-Methylguaiacol & 11.6 & 11.2 & 9.52 & 4.33 \\
\hline 4-Ethylguaiacol & 5.48 & 6.10 & 6.11 & 2.39 \\
\hline 4-Vinylguaiacol & 53.5 & 42.0 & 56.3 & 19.3 \\
\hline 4-Propenylguaiacol & 23.5 & 16.1 & 22.0 & 7.52 \\
\hline \multicolumn{5}{|c|}{ Syringyl-derived compounds } \\
\hline Syringol & 32.3 & 6.17 & 42.1 & 5.60 \\
\hline 4-Methylsyringol & 11.1 & 1.68 & 9.31 & 1.39 \\
\hline 4-Ethylsyringol & 6.23 & 1.17 & 7.59 & 0.88 \\
\hline 4-Vinylsyringol & 40.1 & 4.39 & 40.3 & 4.61 \\
\hline 4-Propenylsyringol & 20.7 & 2.15 & 20.6 & 2.50 \\
\hline S/G ratio & 0.9 & 0.2 & 0.9 & 0.3 \\
\hline
\end{tabular}

$D S$ lavandin stem straw, DF lavandin flower straw, $L S$ lavender stem straw, $L F$ lavender flower straw

a Data are given as peak areas $\left(\times 10^{-6}\right)$ and $S / G$ ratios were calculated based on the peak areas

cocktail, containing mainly cellulase activity [15, 19]. The results after $6 \mathrm{~h}$ of hydrolysis, expressed as glucose equivalents (GluE) in $\mu$ mol per mg DM, are summarized on Fig. 1. The T. reesei cocktail enabled effective release of reducing sugars and glucose. It is worth noting that the release of reducing sugars was 1.7 times higher for the DF and LF fractions (1.2 $\mu \mathrm{mol}$ GluE/mg on average) 


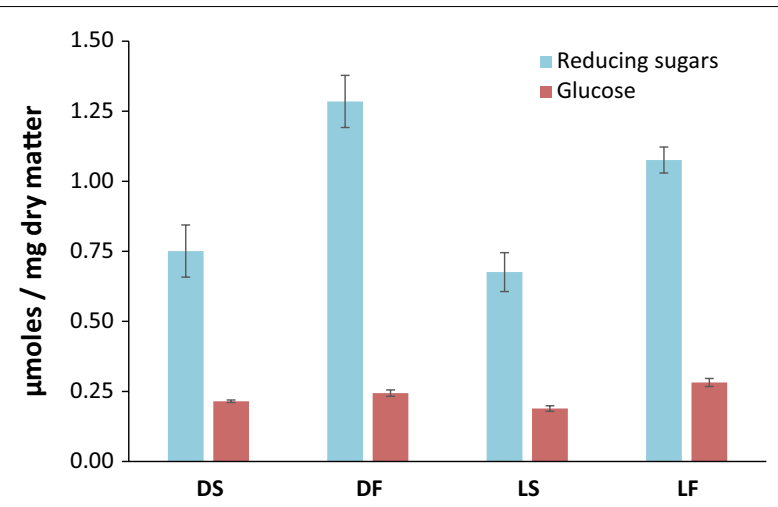

Fig. 1 Saccharification assays of lavandin- and lavender-distilled straws using T. reesei E508 enzymatic cocktail. The reducing sugars and glucose released from the residues were expressed as glucose equivalent (GluE) in $\mu$ mole per mg of dry matter. Values are given at $6 \mathrm{~h}$ and are means of triplicate. Standard errors of the mean were less than $5 \%$

than for DS and LS fractions $(0.72 \mu \mathrm{mol}$ GluE/mg on average). Similarly, glucose release was 1.3 times higher for DF and LF fractions $(0.28 \mu \mathrm{mol} / \mathrm{mg}$ on average $)$ than DS and LS fractions $(0.21 \mu \mathrm{mol} / \mathrm{mg}$ on average). In addition, the release of reducing sugars and glucose was 1.2 times more effective for lavender than for lavandin-distilled straws. As a benchmark, the same T. reesei cocktail enabled the release of $0.98 \mu \mathrm{mol}$ GluE from wheat straw and $0.26 \mu \mathrm{mol}$ GluE from spruce, after $24 \mathrm{~h}$ of incubation [15]. The steam distillation of lavender and lavandin may have functioned as pretreatment, and this may partially explain why the saccharification was higher than that of wheat straw and spruce.

\section{Phenolic and terpene content of LLDS and antiradical activity}

The total phenolic content (expressed as chlorogenic acid equivalents) of the ethanol and ethyl acetate extracts of LLDS was determined for the distilled straw fractions, DS, DF, LS and LF (Table 3). The yield of phenolic compound recovery by ethyl acetate was around $30-35 \%$. In the ethyl acetate extracts, total phenolic content was higher for lavandin fractions, DS and DF (0.77 and $0.79 \mathrm{~g}$ ChAE/100 g DM, respectively) than for lavender fractions, LS and LF (0.60 and $0.62 \mathrm{~g}$ ChAE/100 g DM, respectively). These results were consistent with those of a recent study [9], resulting in a total phenolic content of around $0.8 \mathrm{~g}$ GAE (gallic acid equivalent) in the ethyl acetate fraction per $100 \mathrm{~g}$ of lavandin waste (DM). Stem and flower straws were not separated in that case.

The terpene-enriched cyclohexane fractions and the phenolics-enriched ethyl acetate fractions were analyzed by GC-MS to identify the molecules present in the
Table 3 Total phenolic content of ethanolic and ethyl acetate extracts from distilled straws

\begin{tabular}{|c|c|c|c|c|}
\hline & \multicolumn{2}{|l|}{ Lavandin } & \multicolumn{2}{|l|}{ Lavender } \\
\hline & DS & DF & LS & LF \\
\hline \multicolumn{5}{|l|}{ Ethanolic extract } \\
\hline $\begin{array}{l}{ }^{\mathrm{a} C h A E ~ g / 100 ~ g ~ d r y ~} \\
\text { mass }\end{array}$ & $2.15 \pm 0.07$ & $2.25 \pm 0.21$ & $2.05 \pm 0.21$ & $2.30 \pm 0.22$ \\
\hline \multicolumn{5}{|l|}{ Ethyl acetate extract } \\
\hline $\begin{array}{l}{ }^{\mathrm{a} C h A E ~ g / 100 ~ g ~ d r y ~} \\
\text { mass }\end{array}$ & $0.77 \pm 0.01$ & $0.79 \pm 0.02$ & $0.60 \pm 0.01$ & $0.62 \pm 0.06$ \\
\hline
\end{tabular}

The experiments were performed in duplicate $(n=2)$

$D S$ lavandin stem straw, DF lavandin flower straw, $L S$ lavender stem straw, LF lavender flower straw

a ChAE: chlorogenic acid equivalents ( $\mathrm{g} / 100 \mathrm{~g}$ dry mass of straw)

stems and flowers of LLDS (Table 4). A total of 28 terpene derivatives, lactones and phenolic compounds were identified. Eighteen compounds were detected in the cyclohexane extracts. Coumarin, herniarin, $\mathrm{t}$-cadinol and $\beta$-caryophyllene were common to all the LLDS fractions. Among the terpenes and terpenoids detected, seven were specific for lavandin-straw stems and lavender-straw flowers: $\beta$-myrcene, borneol, cis-geraniol, geranyl propionate, germacrene $\mathrm{D}, \alpha$-bisabolol and camphor. In addition, in this study, seven compounds were found to be common to DS, DF and LS, two monoterpenols (linalool and $\alpha$-terpineol), four terpenic esters (dihydrocarvyl acetate, geranyl acetate, linalyl acetate and neryl acetate) and one sesquiterpene, $\beta$-farnesene. Our results are useful complements to previous studies [20], which found coumarin, dihydrocoumarin, herniarin, $\alpha$ and $\tau$-cadinol, $\alpha$-bisabolol and camphor in the cyclohexanic extract of distilled lavandin (cultivar Grosso) waste. In addition, ten phenolic compounds (mainly derivatives of benzoic and cinnamic acids) were detected in the ethyl acetate extracts. The molecules were identified in all the DS, DF, LS and LF fractions.

Quantitative analysis of aromatics found in the ethyl acetate extracts of LLDS was performed by HPLC after calibration with available commercial standards (Table 5). Only five molecules could be identified as their aglycones, (i) one phenolic acid, rosmarinic acid, an ester of caffeic acid, (ii) two flavonoids, luteolin and apigenin, tri-and tetra-hydroxylated, respectively, and (iii) two lactones, coumarin and herniarin. DF and LF were highproducing fractions of rosmarinic acid (reaching 78 and $67 \mathrm{mg} / 100 \mathrm{~g}$ DM, respectively) and, to a lesser extent, of luteolin and apigenin. Coumarin and herniarin were present almost in all the LLDS fractions and were especially abundant in lavender straws, with values of 27 and 44, and 23 and $74 \mathrm{mg} / 100 \mathrm{~g}$ DM for LS and LF, respectively. 
Table 4 Compounds identified by GC-MS in the cyclohexane and ethyl acetate fractions of distilled straws

\begin{tabular}{|c|c|c|c|c|}
\hline & Compound nature & Compounds & MS fragments ${ }^{\mathrm{a}} \mathrm{m} / \mathrm{z}$ (relative intensity, \%) & Substrates $^{\mathbf{b}}$ \\
\hline \multirow[t]{18}{*}{ Cyclohexane fraction } & Monoterpenes & $\beta$-Myrcene & $M^{+c} 136(2), 41(100), 93(74), 69(68), 39(28), 27(19), 91$ (17) & DS, DF \\
\hline & \multirow[t]{4}{*}{ Monoterpenols } & Borneol & $\mathrm{M}^{+} 154(\mathrm{tr}), 95(100), 41(32), 27(21), 39(20), 110(20), 43(18)$ & DS, DF \\
\hline & & Linalool & $M^{+} 154(\operatorname{tr}), 41(100), 71(64), 43(60), 55(45), 93(39), 69(36)$ & $D S, D F, L F$ \\
\hline & & cis-Geraniol (nerol) & $M^{+} 154(2), 41(100), 69(66), 39(30), 93(26), 53(12), 68(12)$ & $\mathrm{DS}, \mathrm{DF}$ \\
\hline & & a-Terpineol & $\mathrm{M}^{+} 154(\mathrm{tr}), 59(100), 43(74), 93(72), 121(52), 68(44), 136(42)$ & $\mathrm{DS}, \mathrm{DF}, \mathrm{LF}$ \\
\hline & \multirow[t]{5}{*}{ Terpenic esters } & Dihydrocarvyl acetate & $M^{+} 196(\operatorname{tr}), 43(100), 41(59), 39(39), 93(31), 67(28), 53(25)$ & $\mathrm{DS}, \mathrm{DF}, \mathrm{LF}$ \\
\hline & & Geranyl acetate & $M^{+} 196(t r), 69(100), 43(67), 41(65), 68(38), 93(22), 136(17)$ & DS, DT, LF \\
\hline & & Geranyl propionate & $\mathrm{M}^{+} 210(\mathrm{tr}), 41(100), 69(99), 57(76), 29(70), 68(54), 93(42)$ & DS, DF \\
\hline & & Linalyl acetate & $M^{+} 196(\operatorname{tr}), 43(100), 93(82), 41(58), 80(33), 69(24), 55$ (23) & $D S, D F, L F$ \\
\hline & & Neryl acetate & $M^{+} 196(\operatorname{tr}), 69(100), 41$ (70), $43(58), 68(40), 93(36), 80$ (18) & $D S, D F, L F$ \\
\hline & \multirow[t]{3}{*}{ Sesquiterpenes } & $\beta$-Caryophyllene & $\mathrm{M}^{+} 204(\mathrm{tr}), 41(100), 79(41), 91(40), 39(34), 53(30), 77(28)$ & $\mathrm{DS}, \mathrm{DF}, \mathrm{LS}, \mathrm{LF}$ \\
\hline & & $\beta$-Farnesene & $M^{+} 204(2), 41(100), 69(74), 93(37), 39(26), 67(22), 79$ (19) & $D S, D F, L S$ \\
\hline & & Germacrene D & $\mathrm{M}^{+} 204$ (14), 161 (100), 91 (91), 41 (86), $105(80), 79(52), 81$ (52) & $\mathrm{DS}, \mathrm{DF}$ \\
\hline & \multirow[t]{2}{*}{ Sesquiterpenoids } & a-Bisabolol & $\mathrm{M}^{+} 222(\mathrm{tr}), 43(100), 41(70), 69(50), 119(50), 109(42), 67(28)$ & $\mathrm{DS}, \mathrm{DF}$ \\
\hline & & T-Cadinol & $M^{+} 222(\operatorname{tr}), 161$ (100), 43 (99), $119(56), 41$ (51), 105 (47), 204 (34) & $D S, D F, L S, L F$ \\
\hline & Ketones & Camphor & $M^{+} 152(19), 95(100), 41(89), 81(70), 39(50), 55(50), 69(40)$ & $\mathrm{DS}, \mathrm{DF}$ \\
\hline & \multirow[t]{2}{*}{ Lactones } & Coumarin & $\mathrm{M}^{+} 146(91), 118(100), 90(47), 89(39), 63(38), 39(18), 62(16)$ & $\mathrm{DS}, \mathrm{DF}, \mathrm{LS}, \mathrm{LF}$ \\
\hline & & $\begin{array}{l}\text { Herniarin (7-methoxycou- } \\
\text { marin) }\end{array}$ & $M^{+} 176(85), 133(100), 148(69), 77(22), 51(22), 63(18), 105$ (17) & $D S, D F, L S, L F$ \\
\hline \multirow[t]{10}{*}{ Ethyl acetate fraction } & \multirow{10}{*}{$\begin{array}{l}\text { Phenolic acids and } \\
\text { derivatives }\end{array}$} & Caffeic acid isomers & $\mathrm{M}^{+} 398(20), 219$ (100), 73 (94), 396 (92), 397 (38), 191 (22), 381 (21) & DS, DF, LS, LF \\
\hline & & Catechol lactate & $M^{+} 486(5), 267(100), 73(97), 179(28), 268(27), 147(24), 396(17)$ & $\mathrm{DS}, \mathrm{DF}, \mathrm{LS}, \mathrm{LF}$ \\
\hline & & $\mathrm{o} / \mathrm{m}$-Coumaric acid & $M^{+} 308(24), 73(100), 147(67), 293(31), 131(31), 161(27), 75(24)$ & $D S, D F, L S, L F$ \\
\hline & & p-Coumaric acid & $\mathrm{M}^{+} 308(22), 73(100), 75(39), 219(32), 293(30), 249(17), 147(10)$ & $D S, D F, L S, L F$ \\
\hline & & 2-Hydroxybenzoic acid & $M^{+} 282(\operatorname{tr}), 73(85), 135(35), 268(26), 91(14), 269(12), 179(8)$ & $\mathrm{DS}, \mathrm{DF}, \mathrm{LS}, \mathrm{LF}$ \\
\hline & & $\begin{array}{l}\text { 3-(2-Hydroxyphenyl) } \\
\text { propionic acid }\end{array}$ & $\mathrm{M}^{+} 310(45), 73(100), 147(83), 192(73), 295(62), 177(47), 253$ (39) & $D S, D F, L S, L F$ \\
\hline & & $\begin{array}{l}\text { 3-(4-Hydroxyphenyl)lactic } \\
\text { acid }\end{array}$ & $\mathrm{M}^{+} 398(\mathrm{tr}), 73(100), 179(95), 147$ (31), 308 (29), 180 (16), 75 (13) & $D S, D F, L S, L F$ \\
\hline & & trans/cis Ferulic acid & $M^{+} 338(67), 73(100), 204(43), 75(42), 323(33), 308(30), 249(27)$ & $D S, D F, L S, L F$ \\
\hline & & Protocatechuic acid & $\mathrm{M}^{+} 370(46), 73(100), 193(89), 355$ (23), $223(18), 311$ (17), 371 (15) & $D S, D F, L S, L F$ \\
\hline & & Vanillic acid & $M^{+} 312(61), 297(100), 73(81), 267(73), 223(59), 253(42), 75$ (29) & $D S, D F, L S, L F$ \\
\hline
\end{tabular}

tr traces

a MS fragments of compounds present in the ethyl acetate fraction were given as trimethylsilylated derivatives

b DS, lavandin stem straw; DF, lavandin flower straw; LS, lavender stem straw; LF, lavender flower straw

$\mathrm{M}^{+}$: molecular ion (in italic)

Antiradical scavenging activity, estimated as the inhibitory concentration $\mathrm{IC}_{50}$ and expressed as $\mu \mathrm{g} \mathrm{ChAE} / \mathrm{mL}$ of reaction mixture, was evaluated on the ethyl acetate extracts from the different fractions of LLDS. It was compared to the antiradical scavenging activity of the commercial synthetic antioxidant butylhydroxytoluene (BHT) and the two natural compounds (chlorogenic acid and rosmarinic acid) typically found in lavandin straws and known for their antioxidant activity [9], which were used as references (Table 6). For these reference molecules, the rank of antiradical activity, in decreasing order, was rosmarinic acid followed by chlorogenic acid and BHT. All the LLDS samples tested displayed a lower $\mathrm{IC}_{50}$ (i.e. higher antioxidant activity) than BHT. The ethyl acetate extracts, from both lavandin and lavender straws, showed a greater antiradical activity for flowers straws (LF and DF) than for stems straws (LS and DS) with values of 2.44-4.28 and 8.05-8.45 $\mu \mathrm{g} \mathrm{ChAE} / \mathrm{mL}$, respectively.

\section{Secretomics of the fungus $P$. cinnabarinus grown on lavandin and lavender straws}

Lavender- and lavandin-distilled straws fractions were compatible with the growth of P. cinnabarinus BRFM 137. Indeed, growth tests first performed on agar plates containing only lavandin and lavender straw as a carbon source did not show any toxicity of the different fractions for the fungus. Radial growth was not inhibited, being 
Table 5 Aromatic compounds quantified in the ethyl acetate extracts of distilled straws

\begin{tabular}{llllll}
\hline Compound & \multicolumn{2}{l}{ Lavandin } & & \multicolumn{2}{l}{ Lavender } \\
& DS & DF & & LS & LF \\
\hline Phenolics & & & & \\
Rosmarinic acid & $4 \pm 0.2$ & $78 \pm 4$ & & nd & $67 \pm 3$ \\
Luteolin & $3 \pm 0.1$ & $11 \pm 0.6$ & & $3 \pm 0.2$ & $6 \pm 0.3$ \\
Apigenin & nd & $17 \pm 0.9$ & & $1 \pm 0.1$ & $9 \pm 0.5$ \\
Lactones & & & & \\
Coumarin & nd & $25 \pm 1.3$ & & $27 \pm 1.4$ & $44 \pm 2.2$ \\
Herniarin & $8 \pm 0.4$ & $23 \pm 1.2$ & & $23 \pm 1.3$ & $74 \pm 3.7$ \\
\hline
\end{tabular}

The amounts are expressed in $\mathrm{mg}$ per $100 \mathrm{~g}$ of dry matter

The experiments were performed in duplicate $(n=2)$

$D S$ lavandin stem straw, $D F$ lavandin flower straw, $L S$ lavender stem straw, $L F$ lavender flower straw, nd not detected

Table 6 Antiradical activity of ethyl acetate extracts from distilled straws

\begin{tabular}{lc}
\hline Type of compounds or LLDS fraction & $\begin{array}{c}\mathrm{Cl}_{\mathbf{5 0}}(\boldsymbol{\mu g} \mathrm{ChAE} / \mathrm{mL} \\
\text { reaction mixture) }\end{array}$ \\
\hline Rosmarinic acid & $0.70 \pm 0.05$ \\
Chlorogenic acid & $3.19 \pm 0.17$ \\
Butylhydroxytoluene (BHT) & $15.17 \pm 4.57$ \\
DS & $8.05 \pm 0.80$ \\
DF & $2.44 \pm 0.01$ \\
LS & $8.45 \pm 0.37$ \\
LF & $4.28 \pm 0.01$ \\
\hline
\end{tabular}

The experiments were performed in duplicate $(n=2)$

$D S$ lavandin stem straw, $D F$ lavandin flower straw, $L S$ lavender stem straw, $L F$ lavender flower straw

similar or better than on the reference medium containing only maltose (Additional file 1: Figure S1).

To determine the composition of the secretomes (secreted proteins) produced by P. cinnabarinus BRFM 137 during its growth on the LLDS fractions, we performed, by LC-MS/MS, proteomic analysis on the liquid culture supernatants after 3, 7 and 10 days of growth on each fraction and reference medium. Overall, up to 189 proteins were identified by mass-matching against a database derived from the genome annotation of the strain $P$. cinnabarinus BRFM 137 [21] (Table 7; Additional file 2: Data S1).

Due to the high lignocellulose content of LLDS, a special focus was given to the carbohydrate-active enzymes (CAZymes), that encompass enzymes dedicated to the modification and breakdown of plant cell wall polysaccharides [22, 23], and on "auxiliary activities" enzymes (AA, redox enzymes). A large diversity of CAZymes was identified in fungal secretomes with about $50-55 \%$ of the total proteins (Table 7; Additional file 1: Figure S2). To a lesser extent, proteins with predicted proteolytic activity, related to amino acid and lipid metabolism were also identified (Additional file 1: Table S1, Additional file 2: Data S1). The secretome composition slightly differed according to the nature of the LLDS fraction. The DS and LS secretomes have slightly higher proportions of glycoside hydrolases (GHs), carbohydrate esterases (CEs) and AAs than the other secretomes, (Table 7; Additional file 3: Data S2). The AA class encompasses a large group of lignolytic and polysaccharide oxidases, including various enzymes of industrial interest [22]. Interestingly, the secretomes of $P$. cinnabarinus BRFM 137 contained between 14 and 19 different AAs (Table 7), distributed across the (sub)families AA1_1, AA1_2, AA2, AA3_1, AA3_2, AA3_4, AA5_1, AA6 and AA9. Interestingly, AA1_2, AA6, and AA9, were only detected in the LLDS secretomes (Table 7; Additional file 3: Data S2), while AA3_4 (a predicted function of pyranose oxidase) and AA6 (a predicted function of benzoquinone reductase) were only found in the DF-and LF-secretomes. Enzymes from the AA9 family correspond to lytic polysaccharide monooxygenases (LPMOs), which boost the activity of GHs through the oxidative cleavage of recalcitrant polysaccharides. Out of the 16 AA9 LPMOs encoded by the P. cinnabarinus BRFM137 genome, seven were identified in LLDS secretomes. Two of them harbour a CBM1 module that might potentiate their activity on cellulose. Interestingly, the $P$. cinnabarinus cellobiose dehydrogenase (CDH, AA3_1-AA8) providing electron to the LPMOs is also present in LLDS secretomes.

\section{Production of laccase by P. cinnabarinus in the presence of LLDS}

Among the extracellular proteins identified in the secretomes of $P$. cinnabarinus grown in the presence of LLDS, AA1_1 laccases (p-diphenol:oxygen oxidoreductases) were amongst the most abundant proteins secreted. Laccases are multicopper enzymes of industrial interest for white biotechnology [24, 25]. To further investigate the production of laccase, we monitored the laccase activity for 14 days in cultures induced by DS, DF, LS and LF (Fig. 2). Maximum laccase activity (400-540 nkat $/ \mathrm{mL}$ ) was obtained on day 14 of culture, corresponding to $85-125 \mathrm{mg} / \mathrm{mL}$ of enzyme (specific activity of $4330 \mathrm{nkat} / \mathrm{mg}$ [26]), which was 5-7 times higher than the activity obtained in the control medium (75 nkat $/ \mathrm{mL}$ in the absence of any inducer) and 1.5-2 times higher than that obtained in the presence of ferulic acid ( $250 \mathrm{nkat} / \mathrm{mL}$ on average), a phenolic acid conventionally used as laccase inducer [27]. Among the conditions tested, the LS fraction was the most suitable inducer for high laccase production. 
Table 7 Proteins (CAZymes) identified in the $P$. cinnabarinus secretomes

\begin{tabular}{|c|c|c|c|c|c|}
\hline & \multicolumn{2}{|c|}{ Lavandin } & \multicolumn{2}{|c|}{ Lavender } & \multirow{2}{*}{$\begin{array}{l}\text { Reference } \\
\text { Maltose }\end{array}$} \\
\hline & DS & DF & LS & LF & \\
\hline Number of total proteins detected & 153 & 189 & 147 & 176 & 164 \\
\hline Number of predicted CAZymes & 85 & 91 & 81 & 90 & 81 \\
\hline $\mathrm{GH}$ & 56 & 58 & 56 & 61 & 56 \\
\hline$P L$ & 3 & 5 & 2 & 4 & 4 \\
\hline CE & 7 & 8 & 6 & 7 & 6 \\
\hline AA & 17 & 19 & 15 & 17 & 14 \\
\hline AA1_1 (laccases) & 4 & 4 & 4 & 4 & 4 \\
\hline AA1_2 (ferroxidases) & 1 & 1 & 1 & 1 & 0 \\
\hline AA2 (class II peroxidases, manganese peroxidase) & 0 & 0 & 0 & 0 & 1 \\
\hline AA3_1 (cellobiose dehydrogenases) & 1 & 1 & 1 & 1 & 1 \\
\hline AA3_2 (aryl alcohol oxidases/glucose oxidases) & 2 & 3 & 2 & 4 & 4 \\
\hline AA3_4 (pyranose oxidases) & 0 & 1 & 0 & 1 & 1 \\
\hline AA5_1 (copper radical oxidases/glyoxal oxidases) & 2 & 2 & 2 & 2 & 4 \\
\hline AA6 (benzoquinone reductases) & 0 & 1 & 0 & 1 & 0 \\
\hline AA9 (lytic polysaccharide monooxygenases) & 7 & 6 & 5 & 4 & 0 \\
\hline Number of non-CAZy proteins & 70 & 99 & 68 & 87 & 84 \\
\hline
\end{tabular}

$D S$ lavandin stem straw, DF lavandin flower straw, $L S$ lavender stem straw, $L F$ lavender flower straw, GH glycosyl hydrolases, $A A$ auxiliary activities, $P L$ polysaccharide lyases, CE carbohydrate esterases

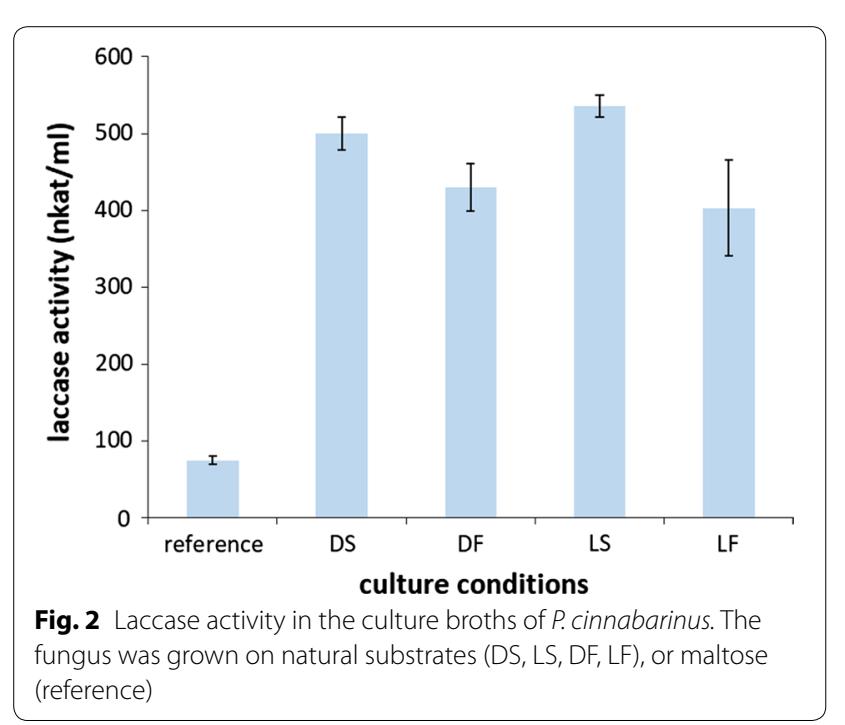

\section{Discussion}

The solid residues obtained after essential oil distillation from lavender and lavandin are generally considered as wastes. This work allowed characterizing lavender- and lavandin-distilled straws as a potentially renewable plant biomass and a source of biomolecules. Diverse ways of valorization were assessed for value recovery.

The cell wall composition of LLDS was determined after fractionation into residual stems, described as a straw-like structure, and residual flowers, the surface of which harbors glandular structures storing essential oil in Lamiaceae [3]. While the straws of lavandin and lavender displayed similar amounts of lignin and cellulose, hemicellulose and pectin contents were higher in lavandin than in lavender straws. In agreement with the literature [10], we found two-fold lower cellulose content in flower straws than in stem straws. Lignin composition of each fraction of lavandin and lavender straws indicated that the flowers, whatever the species (lavandin or lavender) were highly enriched in G-lignin units (S/G ratios of $0.2-$ 0.3 ), while the stem straws had a similar content of both G- and S-lignin units (S/G ratios of 0.9). G-rich lignin produces more condensed linkages because the $\mathrm{C}-5$ position is free to have additional carbon-carbon linkages, thus increasing the recalcitrance of the lignin polymer. More generally, high S/G ratios (at least $>2$ ) can facilitate the enzymatic degradation of the biomass and reduce recalcitrance [28]. Compared to wheat straw and spruce, the saccharification potential of lavender and lavandin straws is promising, considering that the hydrolysis stage can be improved by supplementing the $T$. reesei cocktail with additional fungal enzymes $[15,29]$.

The LLDS fractions contained interesting volatile molecules including terpenes and terpenoids, basically found in the essential oils, as well as non-volatile phenolic compounds and flavonoids which remained in the straws after distillation. Specific solvent extractions coupled with GC-MS and LC analyses enabled us to detect terpene derivatives, lactones and phenolics. Four 
molecules with potential industrial interest were identified in each fraction of distilled straws: (i) the sesquiterpene, $\mathrm{t}$-cadinol, known to have smooth muscle-relaxing properties [30], (ii) the sesquiterpene $\beta$-caryophyllene, which has significant anticancer and analgesic activities [31], and (iii) coumarin and herniarin, which are lactones possessing anti-inflammatory, antioxidant, antiviral, antimicrobial activities, and anti-spasmodic properties [20,32,33]. A wide variety of terpenes and terpenoids, such as linalool, linalyl acetate, borneol, $\alpha$-terpineol and geraniol, all characteristic constituents of lavender and lavandin essential oils, was also recovered from the distilled straws and is known to have sedative, anesthetic, antispasmodic or antimicrobial actions [2]. Vanillic, coumaric and ferulic acids, known as precursors of bioconversion pathways for high-value molecules by filamentous fungi [25], were identified in each LLDS fraction. Chlorogenic acid, glycosylated conjugates of caffeic, ferulic and coumaric acids, and flavonoids (isoquercitrin and luteolin) with strong antioxidant properties have been already identified in lavandin waste [9]. Here, our LC protocol for phenolic compound analysis allowed the identification of rosmarinic acid as the major phenolic compound in the straws, contributing actively to the high radical scavenging capacity of LLDS, as previously reported in the spike lavender by-product obtained after essential oil distillation [5]. Phenolic compounds sharing the ortho-diphenol structure (including caffeic acid or derivatives) are known to be strong antioxidants [34]. Such natural molecules with strong antioxidant activity are progressively replacing synthetic antioxidants such as BHT, whose use is more limited due to possible adverse effects on human health [35]. The extraction of natural antioxidants from agricultural by-products is thus an opportunity to obtain profit from low-cost raw material, such as LLDS, in a sustainable way.

Today, we know that most agricultural by-products (e.g. sugar beet pulp, sugarcane bagasse, oilseed meals) are reliable sources of sugars and/or proteinaceous nutrients and can serve as a support matrix for various biotechnological processes including the fermentative production of enzymes [13]). In microbial, and especially filamentous fungal utilization, agricultural by-products can be used either as a growth carbon substrate and support in solid-state fermentation or as supplement to submerged production media. Here, we showed that LLDS were very good inducers for the production of a large array of lignocellulose-acting enzymes by the model fungus $P$. cinnabarinus, known for its ability to secrete a large panel of hydrolases and oxidoreductases [25]. In particular, LLDS were the best natural laccase inducers known to date for $P$. cinnabarinus; this laccase is a high-redox-potential enzyme already known for its versatility and efficiency in various biotechnological applications [25]. The concomitant induction of a $\mathrm{CDH}$ and several AA9 LPMOs, potentially targeting cellulose, supports a scenario where multiple AA9 LPMOs are required to mediate the decomposition of recalcitrant lignocellulose [36]. Some of these AA9 LPMOs were already detected in the secretomes of $P$. cinnabarinus cultivated on wheat straw [37] or on a mixture of birchwood, cellulose and autoclaved maize bran [21].

\section{Conclusions}

The present study demonstrated that the distilled straws of lavender and lavandin are cheap and readily available industrial by-products of interest for producing high-added value compounds such as platform molecules (e.g. antioxidants) and fungal enzymes involved in the degradation of lignocellulosic biomass. These approaches could represent sustainable strategies to foster the development of a local circular bioeconomy.

\section{Methods \\ Chemicals}

All the chemicals used for the antioxidant measurements (DPPH, 1,1-diphenyl-2-picrylhydrazyl radical) and the total phenol assay (Folin-Ciocalteu reagent), and the phenolic standards (chlorogenic, rosmarinic, caffeic, $p$-coumaric, ferulic, vanillic and protocatechuic acids, and vanillin, luteolin, apigenin, coumarin, herniarin) were purchased from Sigma-Aldrich (SaintQuentin Fallavier, France). Ethanol, ethyl acetate, cyclohexane, and acetonitrile were of HPLC grade and provided by Fisher Scientific (Illkirch-Graffenstaden, France).

\section{Raw materials}

Distilled straws from fine lavender and the Super cultivar of lavandin were provided by the company Bontoux SA (Saint Auban sur l'Ouvèze, France). They were collected at the end of the harvest season (September 2013) just after the steam distillation process and then air-dried at room temperature in the laboratory for 10 days. Dried straws were separated into four fractions: lavandin stems (DS), lavandin flowers (DF), lavender stems (LS) and lavender flowers (LF). Before use, these fractions were ground to obtain particles sized $0.18-0.8 \mathrm{~mm}\left(\mathrm{IKA}^{\circledR}\right.$ A11 knife mill, Werke GmbH \& Co, Staufen, Germany). The dry matter content of each fraction DS, DF, LS and LF was measured by drying until constant mass at $105^{\circ} \mathrm{C}$. 


\section{Fungal strain}

The $P$. cinnabarinus strain used in this study was obtained from the fungal culture collection of the International Centre of Microbial Resources (CIRM-CF) at the French National Institute for Agricultural Research (INRA, Marseille, France). The strain was maintained on malt agar slants at $4{ }^{\circ} \mathrm{C}$, using MA2 (malt extract broth Difco $^{\circledR}$ at $2 \% \mathrm{w} / \mathrm{v}$ ) as medium, under the accession number BRFM 137.

\section{Culture conditions and secretome preparation}

Pycnoporus cinnabarinus strain BRFM 137 was grown on a basal maltose medium [27]. Inoculum was obtained from precultures grown for 10 days at $30{ }^{\circ} \mathrm{C}$ in Roux flasks containing $180 \mathrm{~mL}$ of the following basal medium: maltose $(20 \mathrm{~g} / \mathrm{L})$, diammonium tartrate $(1.84 \mathrm{~g} / \mathrm{L})$, disodium tartrate $(2.3 \mathrm{~g} / \mathrm{L}), \mathrm{KH}_{2} \mathrm{PO}_{4}$ $(1.33 \mathrm{~g} / \mathrm{L}), \quad \mathrm{CaCl}_{2} \cdot 2 \mathrm{H}_{2} \mathrm{O} \quad(0.1 \mathrm{~g} / \mathrm{L}), \quad \mathrm{MgSO}_{4} \cdot 7 \mathrm{H}_{2} \mathrm{O}$ $(0.5 \mathrm{~g} / \mathrm{L}), \quad \mathrm{ZnSO}_{4} \cdot 7 \mathrm{H}_{2} \mathrm{O} \quad(0.046 \mathrm{~g} / \mathrm{L}), \quad \mathrm{MnSO}_{4} \cdot \mathrm{H}_{2} \mathrm{O}$ $(0.035 \mathrm{~g} / \mathrm{L}), \mathrm{CuSO}_{4} \cdot 5 \mathrm{H}_{2} \mathrm{O}(0.007 \mathrm{~g} / \mathrm{L})$, yeast extract $(1 \mathrm{~g} / \mathrm{L})$, and vitamin solution $(1 \mathrm{~mL} / \mathrm{L})$ [38]. Mycelium from two flasks was collected, mixed with $50 \mathrm{~mL}$ sterile water, and blended for $1 \mathrm{~min}$ at $9000 \mathrm{rpm}$ with an Ultra-Turrax T-25 system (Janke \& Kunkel, GMBM \& Co., KG, Staufen, Germany). A 5-mL sample of this suspension was inoculated into basal medium supplemented with $15 \mathrm{~g} / \mathrm{L}$ of autoclaved straws (DS, DF, LS or LF) and $0.05 \mathrm{~g} / \mathrm{L}$ of $\mathrm{CuSO}_{4} \cdot 5 \mathrm{H}_{2} \mathrm{O}$. Mycelial inoculum corresponded to $0.6-0.7 \mathrm{~g}$ mycelium dry mass (DM) per $\mathrm{L}$ of culture medium. Incubation was carried out in the dark at $30{ }^{\circ} \mathrm{C}$ and $120 \mathrm{rpm}$ (Infors HT, Switzerland) in 250-mL baffled Erlenmeyer flasks containing $100 \mathrm{~mL}$ medium, for 10-14 days. Assays were carried out in triplicate.

Cultures were stopped after 3, 7 and 10 days of incubation. Based on previous work [39], the culture broths (secretomes) were separated from the mycelium by filtration through Miracloth ${ }^{\mathrm{TM}}$ paper, centrifuged at $3000 \mathrm{rpm}$ for $15 \mathrm{~min}$ at $4{ }^{\circ} \mathrm{C}$ (Sorvall ST40R, Thermoscientific) and frozen at $-20^{\circ} \mathrm{C}$ until use. The culture supernatants were pooled, filtered (using $0.22 \mu \mathrm{m}$ polyethersulfone membranes, Vivaspin, Sartorius), concentrated (Vivaspin with a $5 \mathrm{kDa}$ cut-off polyethersulfone membrane, Sartorius) to a final concentration of $1 \mathrm{mg} / \mathrm{mL}$, and diafiltered with a $25 \mathrm{mM}$ acetate solution buffer, $\mathrm{pH}$ 5. Total amount of protein was assessed using the Bradford assay (Bio-Rad Protein Assay Dye Reagent Concentrate, Ivry, France) with a BSA standard that ranged from 0.2 to $1 \mathrm{mg} / \mathrm{mL}$.

\section{Identification of proteins by LC-MS/MS analysis}

Proteins from the diafiltered supernatants of $P$. cinnabarinus BRFM 137 cultures, grown on DS, DF, LS, LF or maltose (reference) were separated by one-dimensional (1D) SDS-PAGE electrophoresis [39, 40]. After protein trypsinolysis, peptide analysis was performed by LCMS/MS [40], at the PAPPSO facility platform (Plateforme d'Analyse Protéomique de Paris Sud-Ouest, Jouy-enJosas, France). Based on the list of peptides, protein identification was performed by querying the MS/MS data against the predicted proteins obtained from the $P$. cinnabarinus BRFM 137 genome sequencing data [21], available via the Mycocosm-Joint Genome Institute Portal [41]. Functional annotations with GO, KEGG, KOG and SignalP were obtained from this portal. Proteins identified with at least two unique peptides and a $\log (E$-value $)$ lower than -2.6 were validated. Expert CAZy annotations were performed according to the CAZy database $[22,23,42]$, at the UMR7257 (Architecture et Fonction des Macromolecules Biologiques, Centre National de la Recherche Scientifique, Aix-Marseille Université, Marseille, France).

\section{Laccase assay}

Laccase activity was determined daily in culture supernatants of $P$. cinnabarinus BRFM 137 grown on LLDS throughout the incubation period (up to 14 days) by monitoring $\mathrm{A}_{420}$ (extinction coefficient: $36,000 \mathrm{~L} / \mathrm{mol} \mathrm{cm}$ ) with respect to the rate of oxidation of $500 \mu \mathrm{mol} / \mathrm{L}$ 2,2'-azino-bis-[3-ethylthiazoline-6-sulfonate] (ABTS) in a $50 \mathrm{mmol} / \mathrm{L}$ sodium tartrate buffer $\mathrm{pH} 4$ at $30{ }^{\circ} \mathrm{C}$ [24]. Enzyme activity was expressed in nanokatals (nkat). One nanokatal of activity is defined as the quantity of enzyme causing the conversion of $1 \mathrm{nmol}$ of substrate per second. The experiments were performed in triplicate, and the standard deviation was lower than $5 \%$ of the mean.

\section{Saccharification assays}

The saccharification assays were performed via a previously described high-throughput automated method [43] using a Tecan Genesis Evo 200 robot (Tecan, Lyon, France). A $1 \%(\mathrm{w} / \mathrm{v})$ suspension of each straw fraction (DS, DF, LS and LF) was prepared in $50 \mathrm{mM}$ acetate buffer, pH 5, supplemented with $40 \mu \mathrm{g} / \mathrm{mL}$ of tetracycline as antibiotic and $30 \mu \mathrm{g} / \mathrm{mL}$ of cycloheximide as antifungal agent. After rehydration overnight at $4{ }^{\circ} \mathrm{C}$, the resulting suspensions were robot-dispensed into 96-well plates and the plates were frozen at $-20{ }^{\circ} \mathrm{C}$ until needed. Saccharification was performed after addition of $30 \mu \mathrm{g}$ of Trichoderma reesei E508 enzymatic cocktail produced from $T$. reesei CL847 strain (obtained from IFPEN, Rueil-Malmaison, France) at $37^{\circ} \mathrm{C}$ with $8 \mathrm{~Hz}$ shaking. T. reesei enzyme cocktail contained $0.12 \mathrm{U}$ of filter paper activity, $0.33 \mathrm{U}$ of CMCase, $0.2 \mathrm{U}$ of $\beta$-glucosidase, $1.6 \mathrm{U}$ of xylanase, $0.02 \mathrm{U}$ 
of mannanase and $0.02 \mathrm{U}$ of arabinofuranosidase per mg of total protein [15]. A substrate-free negative control was set up by filling wells with $50 \mathrm{mM}$ sodium acetate buffer, $\mathrm{pH} 5$, and the background of soluble sugars present in the samples was determined by incubating them in the absence of E508 enzymatic cocktail. After 3 and $6 \mathrm{~h}$ of incubation, the saccharification reaction mixtures were filtered and recovered, the reducing sugars were quantified using the 3,5-dinitrosalicylic acid (DNS) method, and glucose content was measured using a Glucose RTU kit (Biomérieux, Marcy l'Etoile, France) following the manufacturer's instructions. The results were expressed as $\mu \mathrm{mol}$ glucose equivalent (GluE)/mg DM. All the reactions were performed independently at least in triplicate.

\section{Analytical methods}

Acid-insoluble lignin content of the straw fractions was determined gravimetrically according to the NREL procedures [44]. After pre-hydrolysis with $72 \%$ (w/w) $\mathrm{H}_{2} \mathrm{SO}_{4}$ for $1 \mathrm{~h}$ at $30{ }^{\circ} \mathrm{C}$, samples were hydrolyzed with $4 \%(\mathrm{w} / \mathrm{w})$ $\mathrm{H}_{2} \mathrm{SO}_{4}$ for $1 \mathrm{~h}$ at $120{ }^{\circ} \mathrm{C}$ and filtered over AP40 Millipore glass-fiber filters. The washed residue was dried $\left(105^{\circ} \mathrm{C}\right.$, overnight), and weighed to give acid-insoluble lignin.

Neutral sugar composition determination was performed as previously described [45]. The samples were freeze-dried prior to analysis. The monosaccharides were quantified after pre-hydrolysis with $72 \%(\mathrm{w} / \mathrm{w}) \mathrm{H}_{2} \mathrm{SO}_{4}$ at $25{ }^{\circ} \mathrm{C}$ for 30 min followed by hydrolysis in $2 \mathrm{~N} \mathrm{H}_{2} \mathrm{SO}_{4}$ at $100{ }^{\circ} \mathrm{C}$ for $2 \mathrm{~h}$ and derivatization into their alditol acetates which were then analyzed by gas chromatography (AutoSystem, Perkin Elmer, Courtaboeuf, France). Chromatography conditions were as follows: silica capillary column BP-225 (25 m $\times 0.32 \mathrm{~mm}$ id, Chromoptic, Courtaboeuf, France), hydrogen as carrier gas at a constant temperature of $220^{\circ} \mathrm{C}$ and a flow rate of $2.2 \mathrm{~mL} / \mathrm{min}$. Myo-inositol was used as internal standard.

Uronic acid content was determined according to the automated $m$-hydroxybiphenyl method using anhydrogalacturonic acid for calibration [46].

The recovery of phenolics present in LLDS was conducted with a two-step extraction procedure. DS, DF, LS and LF fractions (20 g wet mass) were first extracted by maceration with $500 \mathrm{~mL}$ of $80 \%(\mathrm{v} / \mathrm{v})$ ethanol in water for $24 \mathrm{~h}$ at room temperature under gentle stirring. The ethanolic extract was subsequently clarified by filtration through Miracloth ${ }^{\mathrm{TM}}$ paper and Whatman ${ }^{\circledR}$ GF/D glass-fiber filter (Merck Millipore, Fontenaysous-Bois, France). An aliquot of the clarified ethanolic extract $(50 \mathrm{~mL})$ was adjusted to $\mathrm{pH} 3$ with $\mathrm{HCl}$ and then extracted three times successively with the solvent system ethyl acetate/water/ethanol (2:3:1 v/v/v). The enriched phenolic ethyl acetate phases were pooled and dried with anhydrous sodium sulfate. The solvent was further evaporated to dryness and the extract was solubilized in either $2 \mathrm{~mL}$ of ethyl acetate for GC-MS analysis or $2 \mathrm{~mL}$ ethanol for the other subsequent analyses.

For terpene extraction, each distilled straw fraction (5 g wet mass) was extracted two-fold with $120 \mathrm{~mL}$ cyclohexane under reflux for $30 \mathrm{~min}$. After evaporation of the solvent, the terpene extract was totally dried under nitrogen, weighed and dissolved in a minimum volume of cyclohexane for GC-MS analysis.

Total phenolic content was determined colorimetrically at $750 \mathrm{~nm}$ by the Folin-Ciocalteu reagent, using chlorogenic acid as calibration standard. Results of analyses were expressed as g chlorogenic acid equivalents (ChAE) per $100 \mathrm{~g}$ DM. The calibration curve was established from 0 to $100 \mathrm{mg} / \mathrm{L}$ chlorogenic acid.

The antiradical properties of DS, DF, LS and LF extracts were assessed as previously described [47]. Two milliliter of the sample to be tested was added to an ethanolic solution containing $60 \mu \mathrm{M}$ DPPH. After $30 \mathrm{~min}$ in the dark, the absorbance was recorded at $517 \mathrm{~nm}$ and compared against the control (butylhydroxytoluene as synthetic antioxidant). Antiradical activity is defined as the sample concentration $\left(\mathrm{IC}_{50}\right)$ needed to decrease the initial DPPH concentration by $50 \% . \mathrm{IC}_{50}$ was expressed as $\mu \mathrm{g}$ ChAE per $\mathrm{mL}$ of reaction medium. The lower the $\mathrm{IC}_{50}$ value, the more potent the extract scavenges DPPH.

High-performance liquid-chromatography (HPLC) analysis of monophenolics was performed at $220 \mathrm{~nm}$ and $30{ }^{\circ} \mathrm{C}$ on a model Agilent1100 (Agilent Technologies, Massy, France) equipped with a variable UV/Vis detector and a 100-position autosampler/autoinjector. Separations were achieved on a C30 reversed-phase column (YMC ${ }^{\mathrm{TM}}$ Carotenoid $3 \mu \mathrm{m}, 4.6 \times 150 \mathrm{~mm}$, Waters, Guyancourt, France). Flow rate was $0.8 \mathrm{~mL} / \mathrm{min}$. The mobile phases used were $0.05 \%$ phosphoric acid in water (solvent A) and acetonitrile $100 \%$ (solvent $\mathrm{B}$ ). The gradient program was as follows: solvent B started at $15 \%$ for $5 \mathrm{~min}$, increased to $40 \%$ in $15 \mathrm{~min}$, then to $100 \%$ in $5 \mathrm{~min}$ until the end of the run (28 min). Quantification was performed by external standard calibration at concentrations ranging from 0 to $500 \mathrm{mg} / \mathrm{L}$.

The qualitative analyses of samples were achieved using the gas chromatography-mass spectrometry (GC-MS) technique [48]. For phenolic analyses, the samples were submitted to the following procedure for derivatization prior to GC-MS analysis: $297 \mu \mathrm{L}$ of $N$-methyl- $N$ (trimethylsilyl)fluoroacetamide (MSTFA) and $3 \mu \mathrm{L}$ of $2 \%$ $(w / v)$ methoxyamine hydrochloride in pyridine was incubated with the sample for $15 \mathrm{~min}$ at $60{ }^{\circ} \mathrm{C}$. Trimethylsilyl derivatives of monomeric phenolic extracts were then analyzed by GC-MS using an Agilent 6890N GC-5973N mass detector (Agilent Technologies, Massy, France). GC-MS analyses of the terpene-rich cyclohexane 
extracts were performed without prior derivatization. The GC column was an Agilent DB5-MS $(30 \mathrm{~m} \times 0.25 \mathrm{~mm}$ i.d., $0.25 \mu \mathrm{m}$ film thickness) with an inlet system using the 1:20 split injection technique. Injector temperature was $250^{\circ} \mathrm{C}$. Carrier gas was helium at a constant flow rate of $1 \mathrm{~mL} / \mathrm{min}$. For phenolic analyses, the oven temperature was held at $70{ }^{\circ} \mathrm{C}$ for $2 \mathrm{~min}$, then raised to $280{ }^{\circ} \mathrm{C}$ at a rate of $10{ }^{\circ} \mathrm{C} / \mathrm{min}$ and held at $280{ }^{\circ} \mathrm{C}$ for $5 \mathrm{~min}$, then raised up to $300{ }^{\circ} \mathrm{C}$ at a rate of $10{ }^{\circ} \mathrm{C} / \mathrm{min}$, held at $300{ }^{\circ} \mathrm{C}$ for $5 \mathrm{~min}$. Electron impact energy was set at $70 \mathrm{eV}$, ion source temperature was $230{ }^{\circ} \mathrm{C}$ and quadrupole temperature $150^{\circ} \mathrm{C}$. EI mass spectra ranged from 40 to $650 \mathrm{amu}$. For terpene analyses, the oven temperature was held at $50{ }^{\circ} \mathrm{C}$ for $1 \mathrm{~min}$, then raised to $250^{\circ} \mathrm{C}$ at a rate of $4{ }^{\circ} \mathrm{C} / \mathrm{min}$ and held at $250^{\circ} \mathrm{C}$ for $5 \mathrm{~min}$. EI mass spectra ranged from 33 to $300 \mathrm{amu}$. Compounds were identified by comparing the mass spectra against those of the NIST library.

Samples (around $1 \mathrm{mg}$ ) were analyzed by pyrolysis-gas chromatography/mass spectrometry (Py-GC/MS) on a 3030 micro-furnace pyrolyzer (Frontier Laboratories Ltd., Fukushima, Japan) connected to an Agilent 7820A GC system using a DB-1701 fused-silica capillary column $(60 \mathrm{~m} \times 0.25 \mathrm{~mm}, 0.25 \mu \mathrm{m}$ film thickness) and an Agilent 5975 mass selective detector (EI at $70 \mathrm{eV}$ ) (Agilent Technologies, Santa Clara, CA). Pyrolysis was performed at $500{ }^{\circ} \mathrm{C}$. Temperature program of the $\mathrm{GC}$ oven was raised from $100{ }^{\circ} \mathrm{C}(4 \mathrm{~min})$ to $280{ }^{\circ} \mathrm{C}(8 \mathrm{~min})$ at $3{ }^{\circ} \mathrm{C} / \mathrm{min}$. The carrier gas was helium $(1 \mathrm{~mL} / \mathrm{min})$. The compounds were identified by comparing their mass spectra against those of the Wiley and NIST libraries and those reported in the literature $[49,50]$, and when possible, by comparison with the retention times and mass spectra of authentic standards. Peak areas were calculated for the lignin-degradation products, and the ratio of the syringyl-to guaiacyl-derived compounds (S/G ratio) was determined.

\section{Additional files}

Additional file 1. Additional Figures S1 and S2, and Table S1.

Additional file 2: Data S1. Excel table containing the list of proteins detected and identified in the secretomes of P. cinnabarinus BRFM137 grown on DS, DF, LS, LF or maltose (reference) as substrates.

Additional file 3: Data S2. Excel table containing the list of the Auxiliary Activities (AAs) detected and identified in the secretomes of P. cinnabarinus BRFM137 grown on DF, DS, LF, LS or maltose (reference) as substrates.

\section{Abbreviations}

AA: auxiliary activity enzyme; ABTS: 2,2'-azino-bis-[3-ethylthiazoline-6-sulfonate]; BHT: butylhydroxytoluene; BRFM: Banque de Ressources Fongiques de Marseille, France; BSA: bovine serum albumin; CAZy: carbohydrate-active enzymes; CBM: carbohydrate-binding domain; $\mathrm{CDH}$ : cellobiose dehydrogenase; CE: carbohydrate esterases; EG: endoglucanase; GH: glycoside hydrolase; CIRM: International Centre of Microbial Resources; DM: dry matter; DF: the lavandin flower fraction obtained after fractionation of lavandin-distilled straws; DPPH: 1,1-diphenyl-2-picrylhydrazyl radical; DS: the lavandin stem fraction obtained after fractionation of lavandin-distilled straws; G: guaiacyl unit; GC-MS: gas chromatography-mass spectrometry; H: hydroxyl unit; HPLC: high-performance liquid-chromatography; JGI: Joint Genome Institute (USA); $\mathrm{IC}_{50}$ : half-maximal inhibitory concentration; LC-MS/MS: liquid chromatography coupled with tandem mass spectrometry; LF: the lavender flower fraction obtained after fractionation of lavender-distilled straws; LLDS: lavender-and lavandin-distilled straws; LS: the lavender stem fraction obtained after fractionation of lavender-distilled straws; NIST: National Institute of Standards and Technology; NREL: National Renewable Energy Laboratory's; PL: polysaccharide lyase; S: syringyl unit; SDS-PAGE: sodium dodecyl sulfate-polyacrylamide gel electrophoresis.

\section{Authors' contributions}

$A L$ and LLM conceived, designed, supervised the experiments, and wrote the paper. MB performed the experiments, with the support of $A B$ and EO. CG and JCdR contributed to GC-MS and Py-GC/MS analysis. EB and EO performed the sugar analysis of the substrates. DC performed the secretome analysis. DN and ED carried out the expert annotations of the secretomes. JGB brought expertise on lytic polysaccharide monooxygenase annotation. JCS and CBF contributed to the conception of the work and help to write the first draft of the paper. All the authors contributed to finalizing the manuscript. All authors read and approved the final manuscript.

\section{Author details}

${ }^{1}$ UMR1163 BBF Biodiversité et Biotechnologie Fongiques, INRA, Aix Marseille Univ, 13288 Marseille Cedex 09, France. ${ }^{2}$ UMR408 SQPOV Sécurité et Qualité des Produits d'Origine Végétale, INRA, Université d'Avignon, 33 rue Louis Pasteur, 84029 Avignon, France. ${ }^{3}$ UMR1319 MICALIS Microbiologie de I'Alimentation au Service de la Santé Humaine, PAPPSO, INRA, 78352 Jouy-en-Josas Cedex, France. ${ }^{4}$ USC 1408 AFMB Architecture et Fonction des Macromolécules Biologiques, INRA, 13288 Marseille, France. ${ }^{5}$ UR 1268 BIA Biopolymères, Interactions, Assemblage, INRA, 44316 Nantes, France. ${ }^{6}$ Department of Plant Biotechnology, IRNAS, CSIC, Avda. Reina Mercedes, 10, 41012 Seville, Spain.

\section{Acknowledgements}

This work was funded by the French National Institute for Agricultural and Sea Products (FranceAgriMer), the company Naturamole (Susville, France), and the French Pole of Competitiveness for Perfumes, Flavors and Fragrances (PASS pole, Grasse, France). The authors thank Dr Bernard Henrissat's research group (UMR7257 AFMB, Marseille, France), for the CAZy annotations and J. Vigouroux from the Laboratory of Biopolymers Interactions Assemblies (INRA, Nantes, France) for assistance with the analysis of neutral sugars.

\section{Competing interests}

The authors declare that they have no competing interests.

Availability of data and materials

All data generated or analyzed during this study are included in this published article.

Consent for publications

All the authors consented on the publication of this work.

Ethics approval and consent to participate

Not applicable.

Funding

Funding sources have been addressed in the Acknowledgements.

\section{Publisher's Note}

Springer Nature remains neutral with regard to jurisdictional claims in published maps and institutional affiliations.

Received: 29 May 2018 Accepted: 27 July 2018

Published online: 02 August 2018 


\section{References}

1. Aprotosoaie AC, Gille E, Trifan A, Luca VS, Miron A. Essential oils of Lavandula genus: a systematic review of their chemistry. Phytochem Rev. 2017;16:761-99.

2. Lesage-Meessen L, Bou M, Sigoillot JC, Faulds CB, Lomascolo A. Essential oils and distilled straws of lavender and lavandin: a review of current use and potential application in white biotechnology. Appl Microbiol Biotechnol. 2015;99:3375-85.

3. Zheljazkov VD, Cantrell CL, Astatkie T, Jeliazkova E. Distillation time effect on lavender essential oil yield and composition. J Oleo Sci. 2013;62:195-9.

4. Chamber of Agriculture in Provence-Alpes-Côte-d'Azur (PACA) region and PACA Regional council. Etude de la biomasse agricole et de première transformation mobilisable en région PACA; 2009. https://www.yumpu .com/fr/document/view/16637712/etude-de-la-biomasse-agricole-etde-premiere-ademe. Accessed 15 Nov 2013

5. Mendez-Tovar I, Herrero B, Perez-Magarino S, Pereira JA, Asensio-SManzanera MC. By-product of Lavandula latifolia essential oil distillation as source of antioxidants. J Food Drug Anal. 2015;23:225-33.

6. Ratiarisoa RV, Magniont C, Ginestet S, Oms C, Escadeillas G. Assessment of distilled lavender stalks as bioaggregate for building materials: hygrothermal properties, mechanical performance and chemical interactions with mineral pozzolanic binder. Constr Build Mater. 2016;124:801-15.

7. Navarette A, Herrero M, Martin A, Cocero MJ, Ibanez E. Valorization of solid wastes from essential oil industry. J Food Eng. 2011;104:196-201.

8. Parejo I, Viladomat F, Bastida J, Rosas-Romero A, Flerlage N, Burillo J, Codina C. Comparison between the radical scavenging activity and antioxidant activity of six distilled and nondistilled mediterranean herbs and aromatic plants. J Agric Food Chem. 2002;50:6882-90.

9. Torras-Claveria L, Jauregui O, Bastida J, Codina C, Viladomat F. Antioxidant activity and phenolic composition of Lavandin (Lavandula x intermedia Emeric ex Loiseleur) waste. J Agric Food Chem. 2007;55:8436-43.

10. Kaloustian J, Pauli AM, Pastor J. Chemical and thermal analysis of the biopolymers in the lavandin. J Appl Polym Sci. 2000;77:1629-41.

11. Sanchez C. Lignocellulosic residues: biodegradation and bioconversion by fungi. Biotechnol Adv. 2009;27:185-94.

12. Lesage-Meessen L, Lomascolo A, Bonnin E, Thibault JF, Buleon A, Roller M, Asther M, Record E, Colonna Ceccaldi B, Asther M. A biotechnological process involving filamentous fungi to produce natural crystalline vanillin from maize bran. Appl Biochem Biotechnol. 2002;102-103:141-53.

13. Lomascolo A, Uzan-Boukhris E, Sigoillot JC, Fine F. Rapeseed and sunflower meal: a review on biotechnology status and challenges. Appl Microbiol Biotechnol. 2012;95:1105-14.

14. Zhou S, Raouche S, Grisel S, Sigoillot JC, Herpoël-Gimbert I. Efficient biomass pretreatment using the white-rot fungus Polyporus brumalis. Fungal Genet Biol. 2017. https://doi.org/10.4172/2165-8056.1000150.

15. Couturier M, Haon M, Coutinho PM, Henrissat B, Lesage-Meessen L, Berrin JG. Podospora anserina hemicellulases potentiate the Trichoderma reesei secretome for saccharification of lignocellulosic biomass. Appl Environ Microbiol. 2011:77:237-46.

16. Berrin JG, Navarro D, Couturier M, Olivé C, Grisel S, Haon M, Taussac S, Lechat C, Courtecuisse R, Coutinho PM, Favel A, Lesage-Meessen L. Exploring natural fungal biodiversity from tropical and temperate forests to improve biomass conversion. Appl Environ Microbiol. 2012;78:6483-90

17. Singh Arora D, Kumar Sharma R. Ligninolytic fungal laccases and their biotechnological applications. Appl Biochem Biotechnol. 2010. https:// doi.org/10.1007/s12010-009-8676-y.

18. del Río JC. Gutierrez, Martinez A. Identifying acetylated lignin units in non-wood fibers using pyrolysis-gas chromatography/mass spectrometry. Rapid Commun Mass Spectrom. 2004;18:1181-5.

19. Bischof RH, Ramoni J, Seiboth B. Cellulases and beyond: the first 70 years of the enzyme producer Trichoderma reesei. Microb Cell Fact. 2016;15:106. https://doi.org/10.1186/s12934-016-0507-6.

20. Tiliacos C, Gaydou EM, Bessière JM, Agnel R. Distilled lavandin (Lavandula intermedia Emeric ex Loisel) wastes: a rich source of coumarin and herniarin. J Essent Oil Res. 2008;20:412-3.

21. Levasseur A, Lomascolo A, Chabrol O, Ruiz-Dueñas FJ, Boukhris-Uzan E, Piumi F, Kües U, Ram AFJ, Murat C, Haon M, Benoit I, Arfi Y, Chevret D, Drula E, Kwon MJ, Gouret P, Lesage-Meessen L, Lombard V, Mariette J, Noirot C, Park J, Patyshakuliyeva A, Sigoillot JC, Wiebenga A, Wösten HAB, Martin F, Coutinho PM, de Vries RP, Martinez AT, Klopp C, et al. The genome of the white-rot fungus Pycnoporus cinnabarinus: a basidiomycete model with a versatile arsenal for lignocellulosic biomass breakdown. BMC Genomics. 2014;15:486.

22. Levasseur A, Drula E, Lombard V, Coutinho PM, Henrissat B. Expansion of the enzymatic repertoire of the CAZy database to integrate auxiliary redox enzymes. Biotechnol Biofuels. 2013;6:41.

23. Lombard V, Golaconda Ramulu H, Drula E, Coutinho PM, Henrissat B. The carbohydrate-active enzymes database (CAZy). Nucleic Acids Res. 2014:42:D490-5.

24. Lomascolo A, Record E, Herpoel-Gimbert I, Delattre M, Robert JL, Georis J, Dauvrin T, Sigoillot JC, Asther M. Overproduction of laccase by a monokaryotic strain of Pycnoporus cinnabarinus using ethanol as inducer. J Appl Microbiol. 2003;94:618-24.

25. Lomascolo A, Uzan-Boukhris E, Herpoël-Gimbert I, Sigoillot JC, LesageMeessen L. Mini-review. Peculiarities of Pycnoporus species for applications in biotechnology. Appl Microbiol Biotechnol. 2011;92:1129-49.

26. de Wilde C, Uzan E, Zhou Z, Kruus K, Andberg M, Buchert J, Record E, Asther M, Lomascolo A. Transgenic rice as novel production system for Melanocarpus and Pycnoporus laccases. Transgenic Res. 2008;17:515-27.

27. Herpoël I, Moukha S, Lesage-Meessen L, Sigoillot JC, Asther M. Selection of Pycnoporus cinnabarinus strains for laccase production. FEMS Microbiol Lett. 2000;183:301-6.

28. Studer MH, DeMartini JD, Davis MF, Sykes RW, Davison B, Keller M, Tuskan GA, Wyman CE. Lignin content in natural Populus variants affects sugar release. Proc Natl Acad Sci. 2011;108:6300-5.

29. Ravalason H, Grisel S, Chevret D, Favel A, Berrin JG, Sigoillot JC, HerpoëlGimbert I. Fusarium verticillioides secretome as a source of auxiliary enzymes to enhance saccharification of wheat straw. Bioresour Technol. 2012;114:589-96.

30. Claeson P, Zygmunt P, Högestätt ED. Calcium antagonistic properties of the sesquiterpene T-cadinol: a comparison with nimodipine in the isolated rat aorta. Pharmacol Toxicol. 1991;69:173-7.

31. Fidyt K, Fiedorowicz A, Strzadala L, Szumny A. $\beta$-caryophyllene and $\beta$-caryophyllene oxides-natural compounds of anticancer and analgesic properties. Cancer Med. 2016;5:3007-17.

32. Chu CJ, Kemper KJ. Lavender (Lavandula spp.). Longwood Herbal Task Force; 2001. http://jonnsaromatherapy.com/pdf/Chu_Lavender_Pedia tric Education and Research 2001.pdf. Accessed 15 Nov 2013.

33. Nigam S, Rao JV, Jayashree BS. Microbial biotransformation-a novel approach for modification on coumarin substrates. Indian J Biotechnol. 2013;12:379-85.

34. Rice-Evans CA, Miller NJ, Paganga G. Structure-antioxidant activity relationships of flavonoids and phenolic acids. Free Rad Biol Med. 1996;20:933-56.

35. Amorati R, Foti MC. Vallgimigli I. Antioxidant activity of essential oils. J Agric Food Chem. 2013;61:10835-47.

36. Berrin JG, Rosso MN, Abou Hachem M. Fungal secretomics to probe the biological functions of lytic polysaccharide monooxygenases. Carbohydr Res. 2017;448:155-60.

37. Miyauchi S, Navarro D, Grigoriev IV, Lipzen A, Riley R, Chevret D, Grisel S, Berrin JG, Henrissat B, Rosso MN. Visual comparative omics of fungi for plant biomass deconstruction. Front Microbiol. 2016;7:1335.

38. Tatum EL, Barrat RW, Fries N, Bonner D. Biochemical mutant strains of Neurospora produced by physical and chemical treatment. Am J Bot. 1950;37:38-46.

39. Couturier M, Navarro D, Olivé C, Chevret D, Haon M, Favel A, LesageMeessen L, Henrissat B, Coutinho PM, Berrin J-G. Post-genomic analyses of fungal lignocellulosic biomass degradation reveal the unexpected potential of the plant pathogen Ustilago maydis. BMC Genomics. 2012;13:57.

40. Navarro D, Rosso M-N, Haon M, Olivé C, Bonnin E, Lesage-Meessen L, Chevret D, Coutinho PM, Henrissat B, Berrin JG. Fast solubilization of recalcitrant cellulosic biomass by the basidiomycete fungus Laetisaria arvalis involves successive secretion of oxidative and hydrolytic enzymes. Biotechnol Biofuels. 2014;7:143.

41. MycoCosm—JGl Genome Portal. https://genome.jgi.doe.gov/Pycci1/ Pycci1.home.html. Accessed 26 Oct 2017.

42. CAZy (carbohydrate-active enZYmes) Database. http://www.cazy.org/. Accessed 26 Oct 2017.

43. Navarro D, Couturier M, da Silva GGD, Berrin J-G, Rouau X, Asther M, Bignon $C$. Automated assay for screening the enzymatic release of reducing 
sugars from micronized biomass. Microb Cell Fact. 2010. https://doi. org/10.1186/1475-2859-9-58.

44. Sluiter A, Hames B, Ruiz R, Scarlata C, Sluiter J, Templeton D, Crocker D. Determination of structural carbohydrates and lignin in biomass. Laboratory analytical procedure. NREL/TP; 510-42618. Golden: National Renewable Energy Laboratory; 2008.

45. Englyst HN, Cummings JH. Improved method of measurement of dietary fiber as non-starch polysaccharides in plant foods. J Assoc Off Ana Chem. 1988:71:808-14

46. Thibault JF. Automatisation du dosage des substances pectiques par la méthode au méta-hydroxydiphenyl. Lebensm Wiss Technol. 1979;12:247-51.
47. Lesage-Meessen L, Navarro D, Maunier S, Sigoillot J-C, Lorquin J, Delattre M, Simon J-L, Asther M, Labat M. Simple phenolic content in olive oil residues as a function of extraction systems. Food Chem. 2001;75:501-7.

48. Odinot E, Fine F, Sigoillot J-C, Navarro D, Laguna O, Bisotto A, Peyronnet C, Ginies C, Lecomte J, Faulds C, Lomascolo A. A two-step bioconversion process for canolol production from rapeseed meal combining an Aspergillus niger feruloyl esterase and the fungus Neolentinus lepideus. Microorganisms. 2017. https://doi.org/10.3390/microorganisms5040067.

49. Faix O, Meier D, Fortmann I. Thermal degradation products of wood. Holz Roh Werkst. 1990:48:351-4.

50. Ralph J, Hatfield RD. Pyrolysis-GC-MS characterization of forage materials. J Agric Food Chem. 1991;39:1426-37.
Ready to submit your research? Choose BMC and benefit from:

- fast, convenient online submission

- thorough peer review by experienced researchers in your field

- rapid publication on acceptance

- support for research data, including large and complex data types

- gold Open Access which fosters wider collaboration and increased citations

- maximum visibility for your research: over $100 \mathrm{M}$ website views per year

At BMC, research is always in progress.

Learn more biomedcentral.com/submissions 